\title{
Innovation and Reference of American Applied Talents Training Mode under the Background of "Internet Plus"
}

\author{
Jia Cai \\ Shaanxi Institute of International Trade and Commerce, Xi'an, Shaanxi, 712046, China \\ jenny-715@163.com
}

Keywords: Internet plus; USA; Personnel training mode; Educational innovation; Reference

\begin{abstract}
The innovation made by the United States in personnel training mode also has some reference significance to the traditional teaching mode in china. The cultivation of innovative and entrepreneurial undergraduate talents in the United States presents four highlights: the government attaches great importance to education; the school's educational model is constantly innovating; the school enterprise cooperation is tight; and the application of science and technology is widespread. Universities in China should learn from the innovative entrepreneurial talent training experience in promoting reform and innovation and Entrepreneurship Education: "school enterprise integration" and "mixed promotion mode of business incubator" model, "integrated learning" and "promotion model to promote the Internet plus" under the background of MOOC model. Create online courses suitable for in-service workers to improve their professional level; flexible development and popularization of network education, and form a good teaching environment. In order to develop more suitable for China's higher education innovation and entrepreneurial talent training mode.
\end{abstract}

\section{Introduction}

Under the background of the Internet development, the information technology continues to develop and the industry is gradually reformed and optimized. The drawbacks of the traditional knowledge and innovative talents training mode are gradually emerging. The mode of education in the world is aging, which is mainly manifested by the assimilation of talents training mode in universities. Students learn too much knowledge and carry out the social practice of pipeline, innovation ability and its ability to connect with social development is poor, which is out of line with the current needs of talent and the development of science and technology. Therefore, the advanced educators have begun to explore the innovative and entrepreneurial talents training mode [1-2]. These methods have to change the traditional teaching methods, to fully mobilize the enthusiasm of students on the basis of the Internet educational resources, not only cultivate the students' sensitivity in a rapidly changing Internet era of science and technology, but also training students through independent thinking and analysis precision initiative to seize the opportunity, and gradually improve the team cooperation ability. Under the background of information explosion, educational resources are re integrated and re configured [3]. The high-speed update of information and the rapid development of science and technology coexist, and the integration of education and the Internet will never stop on the network learning platform. The innovation of this research is to focus on the four highlights of the training mode of the innovative talents, and puts forward the suitable for China's innovation and entrepreneurship training suggestions according to several typical models are discussed, in order to develop more suitable for Chinese higher education innovation and entrepreneurial talent training mode.

\section{"Internet plus" background}

"Internet plus" is a new Internet business innovation 2 under development, is the innovation of knowledge society 2 to promote the evolution of the Internet and its economic and social development of new forms of birth. "Internet plus" is further practice of the Internet thinking, promote the economy changed, which led to social economy vitality, provide a broad platform for reform, innovation and development. Popular to say, "Internet plus" is the "Internet plus various 
traditional industries", but this is not a simple combination, but the use of information and communication technology and the Internet platform, so that the Internet and traditional industries depth of integration, to create a new ecological development [4-5]. It represents a new social form, that is, to give full play to the optimization and integration of the Internet in the allocation of social resources, and to integrate the innovative achievements of the Internet deeply in the economic and social fields. "Internet plus" represents a kind of new economic form, it refers to the realization of combination of Internet and traditional industries relying on the Internet information technology, to optimize production factors and update the business system and the restructuring of business model and other ways to achieve economic transformation and upgrading. "Internet plus" program aims to give full play to the advantages of the Internet, the Internet and traditional industries depth integration, to enhance the economic productivity of industrial upgrading, and finally realize the increase of social wealth [6].

\section{Highlights of the cultivation of innovative and entrepreneurial talents in the United States}

The training mode of innovative and entrepreneurial talents in the United States is various, so as to cultivate students' comprehensive quality. Under the trend of Internet development, the application oriented Undergraduate Education in the United States has also been integrated into the MOOC, leaderless group discussion and flipped classroom, and gradually formed a relatively perfect new teaching model, and the effect is remarkable [7]. In this regard, we summed up the highlights of the cultivation of innovative and entrepreneurial talents in the United States.

The government attaches great importance to education

The United States government issued corresponding laws and regulations for the cultivation of innovative and entrepreneurial talents, such as "higher education", "national defense education" and "American education rules" in 2000. The support of the government in the laws and regulations makes the universities guarantee the policy in the cultivation of innovative and entrepreneurial talents. At the same time, the U.S. government also provides special funds, such as low interest loans, so that colleges and universities in the innovation and entrepreneurial talent training to get financial support. The policies and measures adopted by the government in the cultivation of innovative and entrepreneurial talents have greatly promoted the cultivation of innovative and entrepreneurial talents.

The educational model of schools is constantly innovating

American universities actively carry out various educational model innovation, such as combination of production and learning, entrepreneurship practice, business incubator and school enterprise cooperation. The school enterprise cooperation mode of Harvard University: enterprises provide professional instructors to colleges and universities; schools provide venues and students [8]. Both of them set up cooperative courses together to participate in the cultivation of innovative and entrepreneurial talents, so that the trained students can better adapt to the needs of social development. The mode of "combination of Minerva University and study" in University of Cincinnati is a large open teaching mode for the society, which enables students to acquire practical skills in the real society and improve their professional confidence and social practice ability.

Close cooperation between school and enterprise

The school personnel closely related to most enterprises and realizes the public teaching, which not only trains the students' practical work ability, but also cultivates their innovative ability. In the face of the increasing demand for innovative and entrepreneurial talents market, the combination of school enterprise teaching makes innovative entrepreneurial talents play a full role, and fully realize their value. 


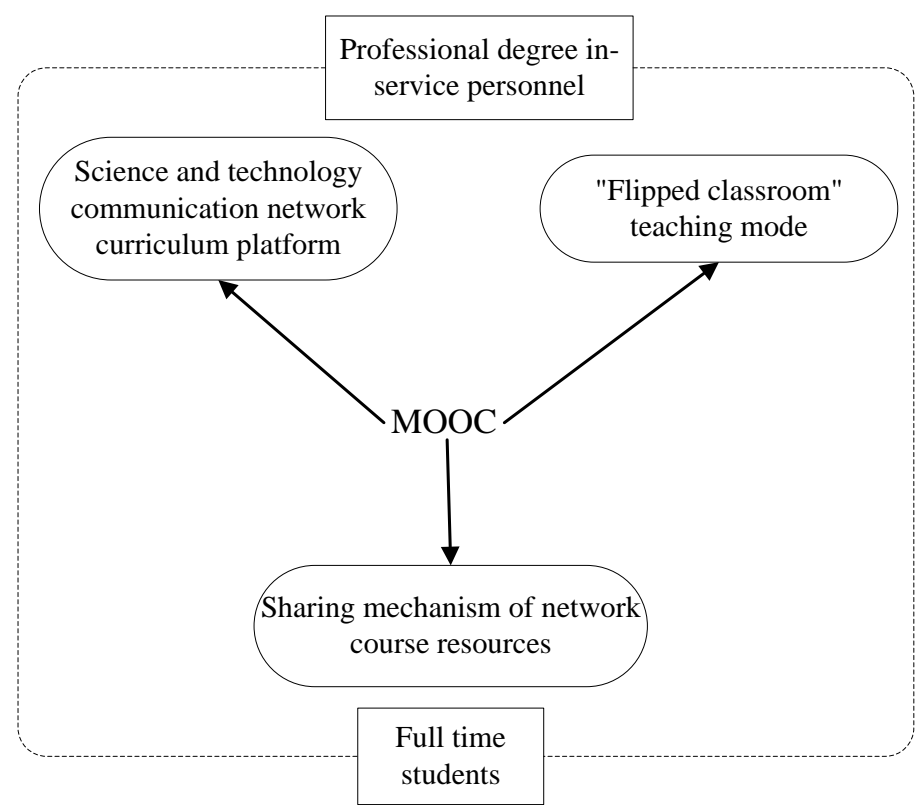

Figure 1. MOOC mode

Wide application of science and technology

With the rapid development of science and technology in the United States, the development of education has been promoted. Education from visual education to audio-visual education and now to the Internet education, this development is inseparable from the development of science and technology [9]. The development of science and technology has not only improved the level of economic development, but also promoted the progress of education. The application of education to science and technology such as MOOC (see figure 1) education model not only realizes the network teaching, but also makes the excellent teachers make full use of it.

\section{The Enlightenment of American new applied talents training mode to China}

\section{To create an online course suitable for in-service workers to improve their diplomas}

American University Now pays more attention to practice and the cultivation of quality and ability in talent training. Combined with the characteristics of compulsory, flexible and self-discipline of the Internet education itself, it can not only train the students' autonomous learning ability, but also meet their personalized development needs. With the rapid development of Internet Education in the United States, the network education in Colleges and universities has been formed, which makes a large number of college students and in-service personnel receive higher education. At present, the world is in the 4 period of industrial transformation and upgrading, which puts forward higher requirements for the workers' own quality and professional skills. China is also in a new wave of industrial upgrading, the need for a large number of high-quality technical personnel [10-11]. Domestic colleges and universities can develop new teaching methods without threshold, which can help the workers who have not received higher education receive higher education, and improve their technical level and self-cultivation.

\section{Try Minerva university creative promotion mode}

"The best way to understand the world is integrated into the world" is to uphold the idea of Minerva. Minerva university admissions process is as shown in figure 2. At present, universities in China generally offer only one academic year or shorter opportunities to communicate abroad. Although not as Minerva universities enable students to walk in the world of learning, but can be combined with their own actual teaching mode follow it, to provide more affordable opportunities to study abroad. Let students learn foreign open thinking, open up the global vision for students, cultivate students' international communication ability and communication level.

Our traditional universities should truly implement the "student center" concept, while copying the MOOC network course, we should not forget face-to-face teacher-student interaction teaching mode. Online and offline courses should be combined to mobilize college students to actively 
participate in the network classroom, and to interact with teachers [12]. Truly improve the quality of education in Colleges and universities, improve students' ability to adapt to society, cultivate students' professional skills and literacy.

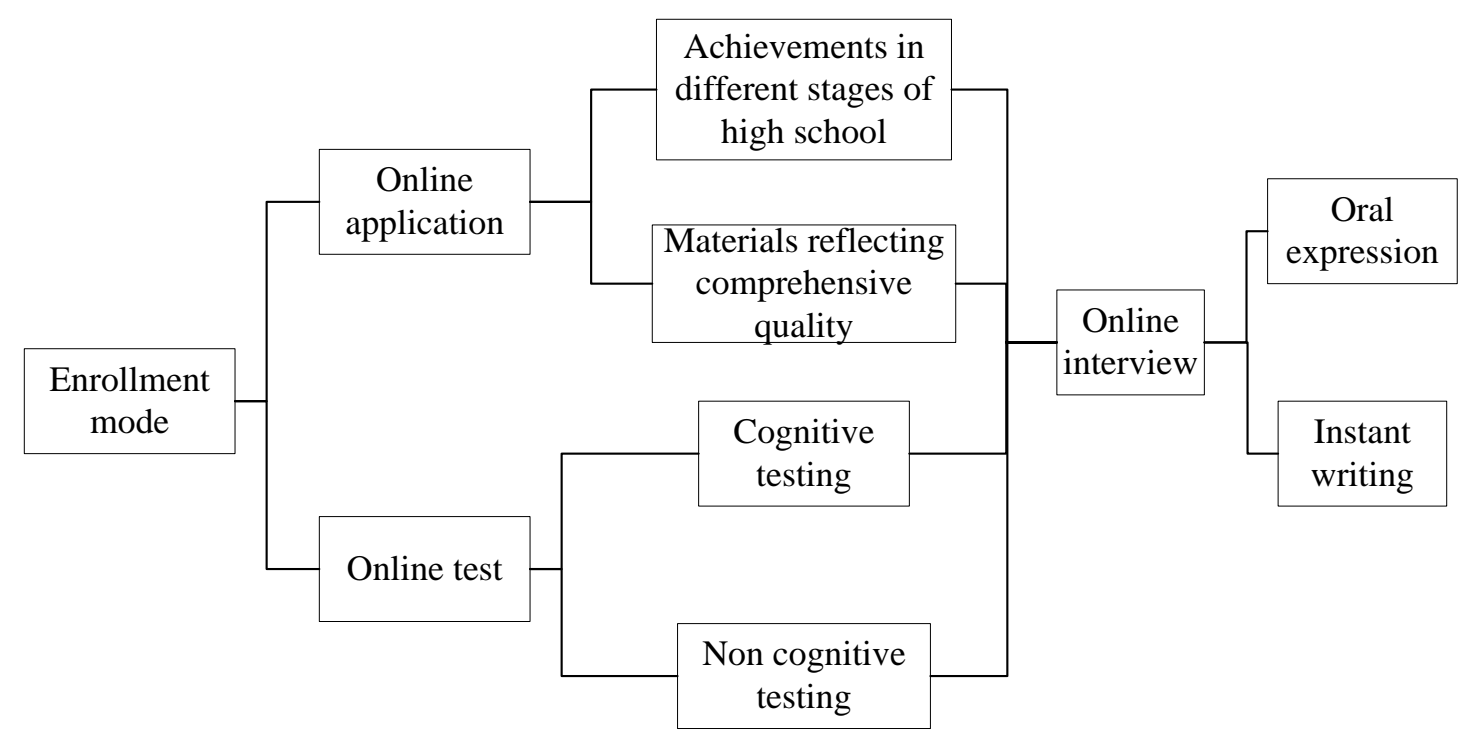

Figure 2. Minerva University admissions process

Domestic universities should also allow students to choose the required courses appropriately and streamline the courses already offered on campus. Through the first year of multi-directional compulsory courses, to help students understand their interests in the field, and in second years to let students choose their professional in-depth study, so that students in the next three years can better learn professional knowledge. In addition, many traditional universities of China opened the compulsory course of a lot of content of such courses are burdensome, streamlining can make students more targeted and more effective.

\section{Flexible development and popularization of network education}

At present, network education has its embryonic form, and has relatively stable technical foundation and educational model. Each school has different educational resources and educational ideas. It should be adapted to the school itself network education according to its own uniqueness and the adaptability to the rapid development of the internet. China's network education is in its infancy, MOOC brings together all kinds of courses at home and abroad, and its quality varies greatly. At present, the popularity of MOOC in China is not high, so the proportion of diploma earned by online students in the school is very low. On-the-job personnel understand and get diploma through MOOC, the proportion of improving their skills is lower. At present, the network education in China is a huge treasure house which has not been fully developed. It is necessary to increase investment, popularize network education and form a good teaching environment, so as to benefit the audience.

\section{Summary}

With the rapid development of economy and science and technology in our country, social demands for talents are constantly improving. In addition to requiring college students to improve their knowledge and skills, they also require college students to continuously improve their social adaptation ability and social communication ability. The current college students and social needs derailed, knowledge learning and social practice is not high and the lack of personalized development, leading to many college graduates unemployed. The innovation made by the United States in personnel training mode also has some reference significance to the traditional teaching mode in china. The network curriculum in Colleges and universities of our country can be created for workers learning to improve their professional level; combined with their actual Minerva follow university teaching mode, students cultivate their international perspective, to improve the professional quality; flexible development and popularization of network education, to create a 
good teaching environment.

\section{References}

[1] Wang X, Sun X, Fengxia L I. The Research and Practice on Applied Talents Training Mode of Based on Collaborative Innovation[J]. Journal of Anyang Institute of Technology, 2016.

[2] Xiaofeng H E, Guo F, Wang R, et al. Innovation and Practice of the Applied-talents Training Mode of Independent College Based on "Three-Trans"[J]. Research \& Exploration in Laboratory, 2017.

[3] Liu T, Dai C, Xu X. Innovation of Applied Talents Training Mode of Environmental Engineering $[\mathrm{J}]$. Office Informatization, 2017.

[4] Hu-Wei L I, Guan W M, Zhao H C, et al. The Research about the Innovative Applied Talents Training Mode of the Mining Engineering__Based on Xinjiang[J]. Education Teaching Forum, 2017.

[5] Ma D, Jia F, Wang W, et al. Practice on reform of innovation-oriented engineering and applied talents training mode based on "Three collaborative effects"[J]. Experimental Technology \& Management, 2017.

[6] Yuan T, Liu Y, Ni C, et al. Construction of Coatings Talents Training Mode of the Pearl River Delta under the Background of Innovation and Pioneering[J]. Guangdong Chemical Industry, 2016.

[7] Jiang L H. Research on the Innovation of Engineering Talents Training Mode Under the Background of " Made in China 2025 " Strategy[J]. Sci-tech Innovation and Productivity, 2016.

[8] Hao L. Local College Economics and Management Innovative Applied Talents Training Mode-Take Economics and Management Professional of a Shaanxi College as an example[J]. Guide of Science \& Education, 2015.

[9] Jiang Y. A Study of the Training Mode of Applied Innovative Talents Based on P-CDIO_—A Case Study of Huzhou Vocational and Technological College[J]. Journal of Continuing Higher Education, 2015.

[10]Zhu L, Tan J, Zheng M, et al. Reform and Exploration of Training Model of Applied Talents Based on Innovative Entrepreneurial Quality[J]. Journal of Higher Education, 2017.

[11] Shi R. The Practice of Cultivating Innovative Talent Training Mode in the Major of Engineering in High Vocational School by"Internet+"__ Taking the Electrical Automation Specialty of Wuxi City College of Vocational Technology as an Example[J]. Computer \& Telecommunication, 2016.

[12]Dehong Y U, Yao Y, Zhao L, et al. Construction of Innovative Ability Training System of Applied Talents for Pharmacy Major in Local Colleges[J]. China Pharmacy, 2017. 